\title{
Evidence of short-term burial response by benthic macrofauna associated with the Mediterranean seagrass Cymodocea nodosa
}

\section{Evidencia de la respuesta a un enterramiento a corto plazo de la fauna macrobentónica asociada a la fanerógama marina del Mediterráneo Cymodocea nodosa}

\author{
Meagan N Schrandt*1,2, Just Cebrián ${ }^{1,2}$, Elizabeth S Darrow ${ }^{1,2}$, D Joseph Dalrymple1,2, C Marco-Méndez ${ }^{3}$, \\ LM Ferrero-Vicente ${ }^{3}$, Kenneth L Heck Jr ${ }^{1,2}$, José Luis Sánchez-Lizaso ${ }^{3,4}$ \\ ${ }^{1}$ Department of Marine Sciences, University of South Alabama, Mobile, Alabama 36688, USA. \\ 2 Dauphin Island Sea Lab, 101 Bienville Blvd., Dauphin Island, Alabama 36528, USA. \\ ${ }_{3}$ Departamento de Ciencias del Mar y Biología Aplicada, Universidad de Alicante, POB 99, E-03080 Alicante, \\ Spain. \\ ${ }^{4}$ Centro de Investigación Marina de Santa Pola, CIMAR, Ayto. de Santa Pola y Univ. de Alicante, Torre \\ d'Enmig s/n, Cabo de Santa Pola, Alicante, Spain. \\ * Corresponding author. E-mail: mschrandt@disl.org
}

\begin{abstract}
Sedimentation and burial affect a variety of habitats worldwide, especially within coastal marine systems. In the Mediterranean, seagrasses like Cymodocea nodosa are commonly subjected to sedimentation and, although the response of C. nodosa has been documented, few studies have included macrofaunal responses. We used a manipulative field experiment to examine the effects of a single small-scale, pulse burial event on benthic invertebrate macrofauna. Burial did not affect the total abundance, richness, or diversity of higher taxa nor the live abundance or diversity after 5 days. However, live higher taxa richness decreased by day 3 . After 5 days, such decrease reversed and partial recovery seemed to occur. Almost 2 months later, three of the buried plots remained with some additional sedimentation, but the other three had lost their sediment. We compared faunal metrics of buried plots between days 5 and 54 and found greater diversity on day 54, providing evidence that macrofaunal recovery apparent 5 days after burial seemed to persist. Although we likely underestimated the effects and can only be conservative with our conclusions, taken together our results suggest small-scale, pulse burial events can have some negative effects on the C. nodosa-associated benthic macrofaunal community, but the community can recover within a few weeks.
\end{abstract}

Key words: benthic macrofauna, Cymodocea nodosa, Mediterranean Sea, recovery, sediment.

RESUMEN. La sedimentación y el enterramiento afectan a una gran variedad de hábitats en todo el mundo, especialmente en los sistemas costeros marinos. En el Mediterráneo, las fanerógamas marinas como Cymodocea nodosa suelen estar expuestas a la sedimentación y, a pesar de que la respuesta de $C$. nodosa ha sido documentada previamente, muy pocos estudios hacen referencia a cómo responde la macrofauna. Se ha usado un experimento manipulativo en el campo para examinar los efectos de un enterramiento súbito y puntual a pequeña escala sobre la fauna de invertebrados macrobentónicos. El enterramiento no afectó a la abundancia total, riqueza o diversidad de especies, ni tampoco a la abundancia o diversidad de individuos vivos 5 días después del enterramiento. Sin embargo, la riqueza de taxones vivos disminuyó a partir del día 3. Pasados 5 días, esa disminución revirtió y parece tener lugar una recuperación parcial. Casi 2 meses después, tres de las parcelas enterradas todavía presentaron algún tipo de sedimentación adicional, pero las otras tres habían perdido el sedimento. Se compararon las métricas de la fauna encontrada en los días 5 y 54 en las parcelas enterradas, y se encontró una alta diversidad para el día 54, evidenciando que la aparente recuperación que tuvo lugar 5 días después del enterramiento parece persistir. A pesar de que probablemente hemos subestimado los efectos y debemos ser conservadores con nuestras conclusiones, al examinar los resultados conjuntamente, sugieren que estos eventos repentinos y puntuales de enterramiento a pequeña escala pueden tener efectos negativos sobre la comunidad de fauna macrobentónica asociada a C. nodosa, la cual se recuperaría en unas pocas semanas.

Palabras clave: macrofauna bentónica, Cymodocea nodosa, mar Mediterráneo, recuperación, sedimento.

\section{INTRODUCTION}

Seagrass meadows are distributed globally and are among the most productive marine ecosystems, providing many goods and services; however, they are also among the most threatened coastal systems with loss rates comparable to coral reefs and mangroves (Waycott et al. 2009). Although

\section{INTRODUCCIÓN}

Las praderas de fanerógamas marinas se distribuyen por todo el mundo y se encuentran entre los ecosistemas marinos más productivos, proporcionando muchos bienes y servicios; sin embargo, también se encuentran entre los ecosistemas costeros más amenazados, con tasas de pérdida comparables 
many causes have been identified for these losses, one of the leading causes of seagrass loss is sedimentation (Short and Wyllie-Echeverria 1996, Duarte 2002, Orth et al. 2006, Cabaço et al. 2008). Seagrasses are typically present in shallow water on soft substrates where physical processes redistribute sediments and can cause burial (Marbà et al. 1994, Cabaço and Santos 2007), thus they are particularly sensitive to intense sedimentation (Marbà and Duarte 1994, Duarte et al. 1997, Terrados 1997).

The macrofaunal communities inhabiting seagrass meadows are also affected by changes in coastal sediment dynamics. Sedimentation events, whether natural or anthropogenic, can cause smothering and mortality (e.g., Peterson et al. 2000, Thrush et al. 2004, Erftemeijer and Robin Lewis 2006, Colosio et al. 2007) if animals are unable to move or cope with burial. Benthic assemblage response to, and recovery from, burial may depend on factors such as sediment particle size, shoreline morphology (e.g., Martin et al. 2005, Colosio et al. 2007), and the ability of the species to migrate to the surface of the newly deposited sediment (Schratzberger et al. 2000, Hinchey et al. 2006). Burial events at varying spatial and time scales can be important determinants of macrofaunal community assemblages.

The seagrass Cymodocea nodosa (Ucria) Ascherson is widely distributed in the Mediterranean Sea where it may form large meadows on shallow reaches of coastal lagoons and sheltered coves (Marbà et al. 1996). It also provides food and refuge for diverse invertebrate and fish assemblages (Tuya et al. 2001, Espino et al. 2011). Yet this species grows in dynamic areas that feature substantial sediment movement (Duarte and Sand-Jensen 1990, Gambi et al. 1998). Although the effects of sedimentation on C. nodosa have been studied previously, the effects on its associated fauna have been scarcely studied. Here we carried out a manipulative field experiment to examine the effects of a small-scale, single pulse burial event on the $C$. nodosa-associated benthic macrofauna. To our knowledge, this is the first study towards assessing the effects of sedimentation on the macrofaunal community associated with $C$. nodosa. Specifically, we monitored the multi-day (5 days) and multi-week (54 days) response of the associated macrofaunal community to a single moderate $(7 \mathrm{~cm})$ or intense $(13 \mathrm{~cm})$ burial event.

\section{MATERIALS AND METHODS}

\section{Study site and experimental design}

The study site was a mixed bed of C. nodosa, Posidonia oceanica, and Caulerpa prolifera, approximately $1 \mathrm{~m}$ deep and located near the Centro de Investigación Marina de Santa Pola (CIMAR) in the Cape of Santa Pola, SE Spain (fig. 1). Within the site, we identified nine patches largely dominated by $C$. nodosa and established three $1-\mathrm{m}^{2}$ plots for each burial treatment (no burial [control], moderate burial, and intense burial). Plots were separated by at least $1 \mathrm{~m}$ and randomly a las de los arrecifes coralinos y manglares (Waycott et al. 2009). Aunque la pérdida de fanerógamas marinas ha sido atribuida a varias causas, la sedimentación es una de las principales (Short y Wyllie-Echeverria 1996, Duarte 2002, Orth et al. 2006, Cabaço et al. 2008), ya que éstas típicamente se encuentran en aguas someras y sustratos suaves donde son más susceptibles a ser enterradas por procesos físicos que redistribuyen los sedimentos (Marbà et al. 1994, Cabaço y Santos 2007). Las fanerógamas marinas son particularmente sensibles a una sedimentación intensa (Marbà y Duarte 1994, Duarte et al. 1997, Terrados 1997).

Las comunidades macrofaunales que habitan las praderas marinas también se ven afectadas por cambios en la dinámica de la sedimentación costera. Los eventos de sedimentación, ya sea naturales o antropogénicos, pueden provocar asfixia y mortalidad (e.g., Peterson et al. 2000, Thrush et al. 2004, Erftemeijer y Robin Lewis 2006, Colosio et al. 2007) si los animales no pueden moverse o lidiar con el enterramiento. La respuesta de las comunidades bentónicas al enterramiento, al igual que su recuperación, depende de factores como el tamaño de grano, la morfología costera (e.g., Martin et al. 2005, Colosio et al. 2007) y la habilidad de las especies para migrar a la superficie del sedimento recién depositado (Schratzberger et al. 2000, Hinchey et al. 2006). Los eventos de enterramiento a diferentes escalas espaciales y temporales pueden ser un factor determinante para las comunidades de macrofauna.

La fanerógama marina Cymodocea nodosa (Ucria) Ascherson, de amplia distribución en el mar Mediterráneo, llega a formar grandes praderas en zonas someras de lagunas costeras y ensenadas resguardadas (Marbà et al. 1996). También proporciona alimento y refugio a diferentes comunidades de invertebrados y peces (Tuya et al. 2001, Espino et al. 2011). No obstante, esta especie crece en zonas dinámicas con importante movimiento sedimentario (Duarte y Sand-Jensen 1990, Gambi et al. 1998). Los efectos de la sedimentación en $C$. nodosa han sido documentados previamente, pero existen pocos trabajos de los efectos en la fauna asociada. En este estudio se realizó un experimento manipulativo en el campo para examinar los efectos de un enterramiento súbito y puntual a pequeña escala sobre la fauna bentónica associada a C. nodosa. Según nuestro conocimiento, éste es el primer estudio que evalúa cómo la sedimentación afecta la comunidad macrofaunal asociada a C. nodosa. Específicamente, se analizó la respuesta durante varios días (5 días) y varias semanas (54 días) de la comunidad macrofaunal associada a $C$. nodoso a un evento único de enterramiento moderado $(7 \mathrm{~cm}) \mathrm{o}$ intenso $(13 \mathrm{~cm})$.

\section{MATERIALES Y MÉTODOS}

\section{Sitio de estudio y diseño experimental}

El sitio de estudio fue una pradera mixta de C. nodosa, Posidonia oceanica y Caulerpa prolifera, de aproximadamente $1 \mathrm{~m}$ de profundidad, localizada cerca del 


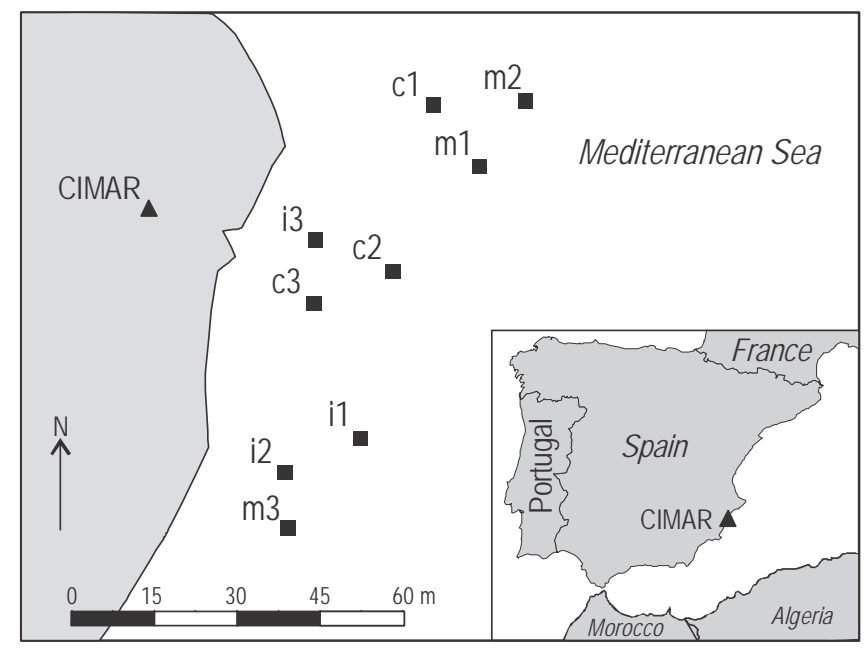

Figure 1. Schematic (not to scale) of the experimental plot set-up off the beach of the Centro de Investigación Marina de Santa Pola (CIMAR), SE Spain. Black squares indicate the experimental plots and labels indicate the burial treatment ( $\mathrm{c}=$ control; $\mathrm{m}=$ moderate; $\mathrm{i}=$ intense) followed by replicate.

Figura 1. Representación gráfica (fuera de escala) del montaje experimental en frente de la playa del Centro de Investigación Marina de Santa Pola (CIMAR), SE de España. Los cuadros negros indican las parcelas experimentales, y las letras indican el tratamiento de enterramiento $(\mathrm{c}=$ control, $\mathrm{m}=$ moderado, $\mathrm{i}=$ intenso) y los números la réplica.

assigned to the burial treatments. To avoid interfering with faunal movements, plots were not surrounded by a hard wall and solely marked with rebar stakes and floats at the corners. Before burial, three haphazard counts of $C$. nodosa shoot density were taken in each plot using a $10 \times 10 \mathrm{~cm}$ metal quadrat.

We obtained sediment from the adjacent beach on day 0 of the experiment. This sediment was mainly composed of fine sand (typical of pulse burial events in this region of the Mediterranean; Manzanera et al. 1998, 2011; GonzálezCorrea et al. 2009). Large debris (e.g., stones, sticks, trash, etc.) was removed and we placed the sediment in containers and used a small boat for transport to the seagrass bed, minimizing trampling on the seagrass habitat. Upon arrival at each plot, a $\sim 0.5-\mathrm{m}$ diameter tube was held above the plot approximately $30 \mathrm{~cm}$ off the bottom so that the other end of the tube was exposed above the water line. The tube was then used to funnel the beach sediment onto the plot. We monitored the burial event via snorkel and made an effort to distribute the sand homogeneously throughout the plot. Sediment depth measurements taken throughout the plot confirmed that we added approximately $7 \mathrm{~cm}$ of sediment to the moderate burial treatment and $13 \mathrm{~cm}$ to the intense burial treatment (see fig. 2). Moderate burial covered about half of the $C$. nodosa leaf canopy and intense burial covered most of it. The experiment was started on 1 September 2011 (day 0) and ended on 25 October 2011 (day 54).
Centro de Investigación Marina de Santa Pola (CIMAR) en el cabo de Santa Pola, sureste de España (fig. 1). Dentro del área de estudio, se identificaron nueve parches dominados principalmente por $C$. nodosa donde se establecieron tres parcelas de $1 \mathrm{~m}^{2}$, separadas entre sí por una distancia de $1 \mathrm{~m}$, para cada tratamiento de enterramiento (enterramiento intenso, enterramiento moderado y sin enterramiento [control]). Los tratamientos fueron asignados aleatoriamente a las parcelas. Para no interferir con el movimiento de la fauna, no se emplearon paredes rígidas para delimitar las parcelas, que se marcaron empleando únicamente barras de hierro y boyas en las esquinas. Antes del enterramiento, se realizaron tres conteos al azar de la densidad de los haces de C. nodosa en cada parcela con un cuadrado de metal de $10 \times 10 \mathrm{~cm}$.

El día 0 del experimento se recolectó sedimento de la playa adyacente, compuesto principalmente por arena fina, (típico de eventos súbitos de enterramiento en esta región del Mediterráneo; Manzanera et al. 1998, 2011; González-Correa et al. 2009). Después de retirar los fragmentos de desechos grandes (e.g., piedras, palos, basura, etc.), el sedimento se colocó en contenedores que fueron transportados en una embarcación pequeña a las praderas marinas, donde se tuvo cuidado de minimizar el pisoteo del hábitat. En cada parcela, un tubo de $\sim 0.5 \mathrm{~m}$ de diámetro se sostuvo aproximadamente $30 \mathrm{~cm}$ por arriba del fondo para que el otro extremo del tubo quedara expuesto por arriba de la línea del agua. El tubo fue utilizado como embudo para vertir el sedimento sobre la parcela. Se hizo un esfuerzo para distribuir la arena homogéneamente en toda la parcela y se usó un tubo de respiración para observar el evento de enterramiento. Las mediciones de la profundidad del sedimento realizadas en toda la parcela confirmaron que se virtieron aproximadamente 7 y $13 \mathrm{~cm}$ de sedimento sobre las parcelas sometidas a enterramiento moderado o intenso, respectivamente (ver fig. 2). El enterramiento moderado cubrió como la mitad de la superficie foliar de $C$. nodosa y el intenso casi toda. El experimento comenzó el 1 de septiembre de 2011 (día 0) y finalizó el 25 de octubre de 2011 (día 54).

\section{Dinámica de enterramiento y mediciones de las plantas}

Para evaluar la consistencia de los tratamientos, se midió la profundidad del sedimento vertido en las parcelas el día 0 , inmediatamente después del enterramiento, y los días 3, 5, y 54 después de añadir el sedimento. Se insertó al azar una regla en el sedimento hasta alcanzar el fondo firme y se registraron un promedio de cinco mediciones por parcela. El fondo natural era compacto y fácilmente distinguible de la arena añadida por presentar resistencia a la regla. También se vigiló si había sedimentación en las parcelas no enterradas (parcelas control) durante el experimento midiendo la distancia entre la parte superior de las barras de hierro y el fondo. El depósito de sedimento en las parcelas control después del enterramiento se derivó como la diferencia entre 


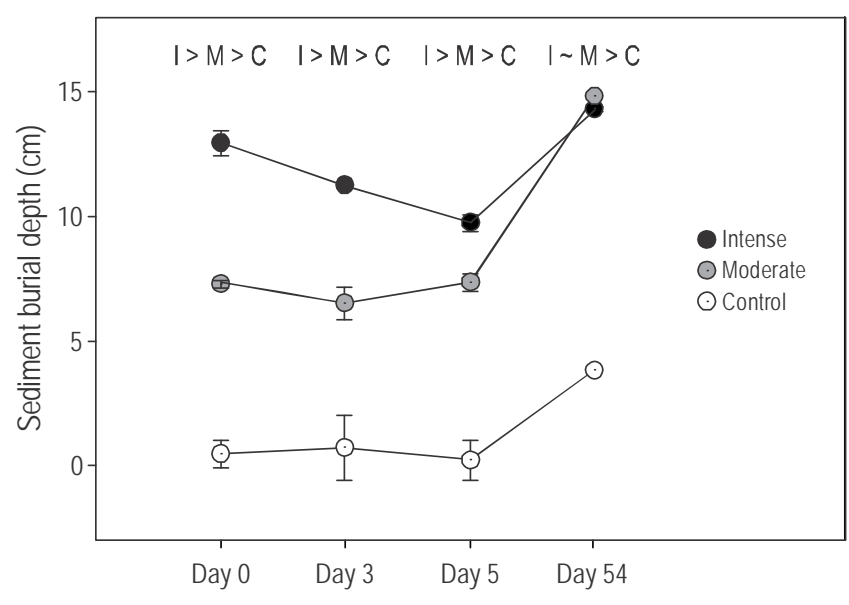

Figure 2. Sediment burial depth for each treatment when a macrofauna core sample was taken. Sample sizes are three for each treatment on days 0,3 , and 5, and two for the control and intense treatments on day 54. Sediment depth for the one remaining moderate burial plot 54 days after burial has been included in the figure for reference. Letters indicate differences among treatments according to Tukey HSD pairwise tests after a significant interaction was detected; pairwise tests were conducted for each time.

Figura 2. Profundidad del sedimento de enterramiento en cada tratamiento al tomar un núcleo de sedimento para evaluar la macrofauna. Se tomaron tres muestras para cada tratamiento en los días 0,3 y 5 , y dos muestras para los tratamientos control y de enterramiento intensivo en el día 54. Se muestra la profundidad del sedimento en la única parcela de enterramiento moderado que sobrevivió al día 54 como referencia. Las letras indican las diferencias entre los tratamientos según la prueba HSD de Tukey por pares después de detectar una interacción significativa; las pruebas por pares se realizaron para cada tiempo.

\section{Burial dynamics and plant measurements}

To evaluate consistency of burial treatments, the depth of the sediment added to buried plots was measured on day 0 immediately after burial and on days 3, 5, and 54 after the sediment was added. A ruler was haphazardly inserted into the sediment deposited onto the plots until the firm bottom was reached, and an average of five measurements per plot was recorded. The natural bottom in the study location was compact and easily distinguishable from the added sand by resistance to the ruler. We also monitored whether sedimentation occurred on control plots during the experiment by measuring the distance from the top of each rebar stake to the bottom. Sediment deposition in control plots on subsequent days after the burial event was derived as the difference between the distance from the top of the rebar stake to the bottom on the given day and the distance at day 0 .

We also measured canopy height on day 0 before burial and on day 5. At five haphazard locations per plot, the length of the leaf canopy (i.e., length from the bottom to the top of the longest leaf among the shoots located within a $\sim 3$-cm circle around the ruler) was measured, and the five la distancia de la parte superior de la barras de hierro y el fondo ese día y la distancia medida el día 0 .

También se midió la superficie foliar el día 0 antes del enterramiento y el día 5 después del evento. En cinco sitios aleatorios de cada parcela, se midió la longitud de la superficie foliar (i.e., longitud de la parte inferior a la parte superior de la hoja más larga entre los haces ubicados dentro de un círculo de $\sim 3 \mathrm{~cm}$ alrededor de la regla); las cinco mediciones se promediaron para obtener una superficie foliar media por parcela. Se calcularon los cambios en la superficie foliar como la diferencia entre el valor medio 5 días después del enterramiento y el valor antes del evento. Reconocemos que las mediciones de fanerógamas marinas de sólo 5 días tienen un valor limitado, pero consideramos que esta información representa un resultado adicional potencialmente útil para realizar comparaciones con reportes previos sobre cómo responde la foliación a un evento de enterramiento. Una cuantificación minuciosa de los efectos de enterramiento sobre $C$. nodosa no era el objetivo de este experimento, sino más bien la respuesta de su comunidad macrofaunal ya que ha sido poco estudiada.

\section{Mediciones de la macrofauna}

Para evaluar la respuesta de la comunidad de fauna macrobentónica asociada a $C$. nodosa al enterramiento, se recolectaron núcleos de sedimento con un tubo de $\mathrm{PVC}$ (8.3 cm de diámetro) en cada parcela antes del enterramiento y en los días 3, 5 y 54 después del evento. Se insertó el nucleador dentro del sedimento añadido y después dentro del sedimento natural hasta una profundidad de $10 \mathrm{~cm}$. Esto equivalió a núcleos de aproximadamente $10 \mathrm{~cm}$ para las parcelas control, $17 \mathrm{~cm}$ para las parcelas expuestas a enterramiento moderado (10 cm más los $7 \mathrm{~cm}$ añadidos) y $23 \mathrm{~cm}$ para las parcelas expuestas a enterramiento intenso $(10 \mathrm{~cm}$ más los $13 \mathrm{~cm}$ añadidos) (ver fig. 2). Los núcleos se colocaron en bolsas de luz de malla de $0.5 \mathrm{~mm}$, se lavaron en el campo y se transportaron al laboratorio donde se tamizaron cuidadosamente a través de una malla de $0.5 \mathrm{~mm}$ de abertura. La macrofauna fue identificada hasta el nivel taxonómico más bajo posible según el tiempo y la experiencia $\mathrm{y}$, por lo tanto, algunos taxones se combinaron en categorías de orden superior. Los taxones $(N=12)$ considerados aquí son los siguientes: Nemertea y Nematoda (nivel filo); Gastropoda, Bivalvia, Polychaeta y Pycnogonida (nivel clase); Oligochaeta (nivel subclase); y Amphipoda, Cumacea, Decapoda, Harpacticoida e Isopoda (nivel orden). Todas las etapas de vida encontradas fueron adscritas a los taxones apropiados. Reconocemos que este nivel de resolución sólo puede detectar los cambios en la composición de la comunidad macrofaunal que suceden a un alto nivel taxonómico (i.e., orden y superior). Algunos investigadores han mostrado que los impactos de eventos estresantes pueden volverse menos perceptibles cuando se cambia el análisis de niveles 
measurements were averaged to yield a mean canopy height per plot. Change in canopy height was calculated as the difference between the mean value 5 days after burial and the value before burial. We acknowledge that seagrass measurements over 5 days have limited value; however, we think this information represents a potentially useful additional result for comparison to past reports of leaf growth response to burial. A thorough quantification of burial effects on the seagrass $C$. nodosa was not the focus of this experiment, but rather the response by its macrofaunal community since it has been scarcely studied.

\section{Macrofaunal measurements}

To assess the response of the $C$. nodosa macrofaunal community to experimental burial, one PVC core $(8.3-\mathrm{cm}$ diameter) was taken from each plot one day prior to burial and on days 3, 5, and 54 after burial. The corer was inserted through the added sediment and then into the natural sediment to a depth of $10 \mathrm{~cm}$. This equated to cores of approximately $10 \mathrm{~cm}$ for control plots, $17 \mathrm{~cm}(10 \mathrm{~cm}$ plus the $7 \mathrm{~cm}$ added) for moderate burial plots, and $23 \mathrm{~cm}(10 \mathrm{~cm}$ plus the $13 \mathrm{~cm}$ added) for intense burial plots (see fig. 2). Cores were placed into a $0.5-\mathrm{mm}$ mesh bag, rinsed in the field and transported to the laboratory where they were carefully sieved on a $0.5-\mathrm{mm}$ mesh. Macrofauna were identified to the lowest practical taxonomic level based on time and expertise, which resulted in some taxa being combined into higher-order taxa. The taxa $(N=12)$ considered here are as follows: Nemertea and Nematoda (phyla level); Gastropoda, Bivalvia, Polychaeta, and Pycnogonida (class level); Oligochaeta (subclass level); and Amphipoda, Cumacea, Decapoda, Harpacticoida, and Isopoda (order level). All life stages encountered were accurately ascribed to the appropriate taxon. We recognize that this level of resolution can only detect changes in macrofauna community composition that occur at a high taxonomic level (i.e., order and above). Other researchers have shown that stressor impacts may become less discernible as we shift the analysis from low (i.e., species, genus, and family) to higher taxonomic levels; however, similar trends have been detected with various taxonomic levels (e.g., Warwick 1988, Olsgard and Somerfield 2000, Dethier and Schoch 2006). Thus, our study may be missing some burial impacts on community composition that occur at low taxonomic levels.

Organisms obtained pre-burial and on days 3 and 5 after burial were processed immediately following collection. In the laboratory they were identified, counted, and classified as either alive or dead. Crustaceans and amphipods were considered alive if they were moving or moved in response to probing; bivalves were considered alive if the shell was closed tight, and they were considered dead if tissue was present within an open shell; polychaetes and other worms were considered alive if the whole animal was present and moving, or moved in response to probing, and they were considered dead if only the head was present. Organisms taxonómicos bajos (i.e., especie, género y familia) a más altos; sin embargo, se han detectado tendencias similares con varios niveles taxonómicos (e.g., Warwick 1988, Olsgard y Somerfield 2000, Dethier y Schoch 2006). Por lo tanto, nuestro estudio podría estar omitiendo algunos de los impactos del enterramiento en la composición de la comunidad que suceden a bajos niveles taxonómicos.

Los organismos recolectados antes del enterramiento y en los días 3 y 5 después del evento fueron procesados inmediatamente en el laboratorio, donde fueron identificados, contados y clasificados como vivos o muertos. Los crustáceos y anfípodos fueron clasificados como vivos si se movían o si se movían en respuesta a la estimulación; los bivalvos se clasificaron como vivos si la concha estaba bien cerrada y como muertos si presentaban tejido dentro de una concha abierta; los poliquetos y otros gusanos fueron clasificados como vivos si el animal estaba entero y se movía, o si se movía en respuesta a la estimulación, y fueron clasificados como muertos si sólo se encontraba la cabeza. Los organismos recolectados el día 54 después del enterramiento fueron fijados en formalina para su posterior identificación. Las mediciones de la macrofauna incluyeron abundancia, riqueza taxonómica (i.e., número de taxones) y el índice de diversidad de Shannon-Wiener $\left(\mathrm{H}^{\prime}\right.$, definido como $\Sigma(\mathrm{Pi} \times \log (\mathrm{Pi}))$ donde Pi es la abundancia proporcional de cada taxón). La abundancia se expresó por área de superficie y por volumen. La abundancia por área de superficie corresponde al número de individuos dividido por el área de superficie del núcleo. La abundancia por volumen corresponde al número de individuos dividido por el volumen total muestreado por el núcleo (i.e., $10 \mathrm{~cm}$ por debajo de la superficie del fondo más el sedimento por encima en las parcelas enterradas).

\section{Análisis estadísticos}

Los cambios en la profundidad del sedimento en las parcelas fueron evaluados mediante un análisis de varianza (ANOVA) de dos vías, con la intensidad de enterramiento y el tiempo desde el enterramiento como factores, seguido por comparaciones múltiples con la prueba HSD (honestly significant difference) de Tukey según fuera apropiado. Los cambios en la altura de la superficie foliar fueron comparados entre los tres tratamientos de enterramiento mediante un ANOVA de una vía, seguido por comparaciones múltiples con la prueba HSD de Tukey.

La respuesta de la macrofauna al enterramiento se analizó mediante un ANOVA de dos vías con medidas repetidas, con intensidad de enterramiento como factor entresujetos $\mathrm{y}$ tiempo como el factor intrasujetos. Se realizaron análisis separados para la fauna viva y total (i.e., viva + muerta). Estuvimos particularmente interesados en el término de interacción entre la intensidad del enterramiento y el tiempo ya que este término mostró si las diferencias (o falta de diferencias) en las métricas de la fauna medidas entre las parcelas antes del evento permanecían inalteradas 
obtained on day 54 after burial were fixed in formalin for later identification. Macrofaunal measurements included abundance, taxonomic richness (i.e., number of taxa), and the Shannon-Wiener diversity index $\left(\mathrm{H}^{\prime}\right.$, defined as $\Sigma(\mathrm{Pi} \times \log$ (Pi)) where $\mathrm{Pi}$ is the proportional abundance of each taxon). Abundance was expressed per surface area and per volume. Abundance per surface area corresponds to the number of individuals divided by the surface area of the core. Abundance per volume corresponds to the number of individuals divided by the total volume sampled in the core (i.e., $10 \mathrm{~cm}$ beneath the natural bottom surface plus sediment above it in the buried plots).

\section{Statistical analyses}

Changes in sediment depth in the plots were evaluated using a two-way analysis of variance (ANOVA), with burial intensity and time-since-burial as factors, followed by Tukey HSD multiple comparisons as pertinent. Changes in leaf canopy height were compared among the three burial treatments with a one-way ANOVA followed by Tukey HSD multiple comparisons.

The response of macrofauna to burial was analyzed with a two-way repeated-measures ANOVA, with burial intensity as the among-subject factor and time as the within-subject factor. Separate analyses were done for live and total (i.e., live + dead) fauna. We were particularly interested in the interaction term between burial intensity and time because this term revealed whether the differences in (or lack of) faunal metrics measured among plots prior to burial remained unaltered (nonsignificant interaction), or else were modified (significant interaction) after the plots were buried. Thus, a significant interaction would suggest significant burial impacts, whereas the lack of a significant interaction would reflect nondetectable burial impacts. If a significant interaction term was obtained, Tukey HSD multiple comparison tests were performed among treatments on each separate day to further investigate the macrofaunal response.

For all analyses, significance was defined at $\alpha=0.05$. The Shannon-Wiener diversity index was calculated with Primer v6.0 and all statistical tests (including statistical power analysis for the performed tests) were done in SigmaPlot 11.0, after confirming assumptions of parametric tests.

\section{RESULTS}

Prior to burial, C. nodosa density ranged, among plots, from $467 \pm 58$ to $733 \pm 102$ shoots $\mathrm{m}^{-2}$ and did not differ significantly among treatments $\left(F_{2,6}=3.09 ; P=0.12\right)$. All three treatments showed an increase in canopy height 5 days after the start of the experiment, but the increase was greater in intense burial plots than control plots (fig. 3) $\left(F_{2,6}=6.80\right.$; $P=0.029$; Tukey HSD, control vs intense $P=0.0312$, control $v s$ moderate $P=0.0671$, moderate $v s$ intense $P=0.8115$ ).

The experiment was designed to study the macrofauna response to burial over a nearly two month period (54 days).

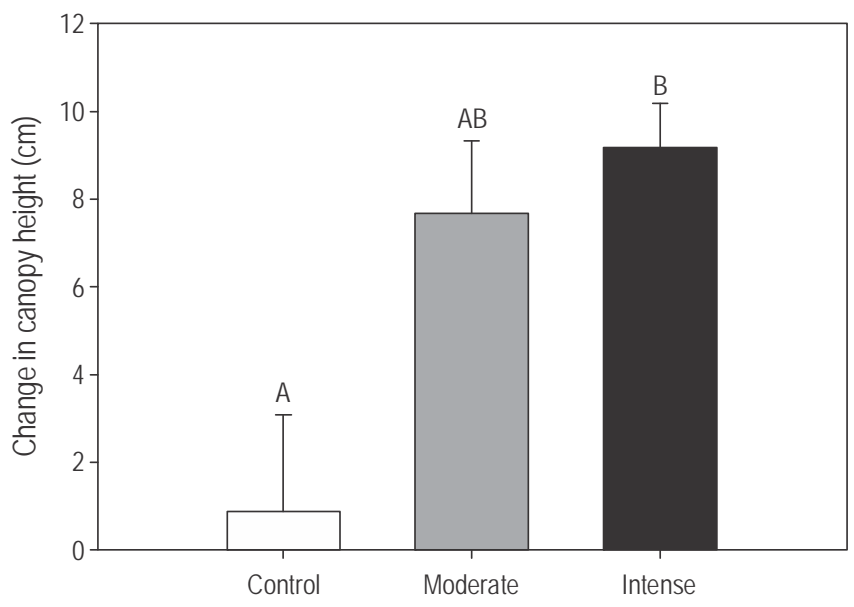

Figure 3. Effect of short-term burial on Cymodocea nodosa canopy height measured before burial and 5 days post-burial. Letters denote the results of the Tukey HSD test. In all figures, data are presented as mean \pm standard error of the mean.

Figura 3. Efecto de un enterramiento a pequeña escala sobre la altura de la superficie foliar de Cymodocea nodosa medida antes del enterramiento y 5 días después del evento. Las letras indican los resultados de la prueba HSD de Tukey. En todas las figuras, los datos se presentan como la media \pm error estándar.

(interacción no significativa) o se habían modificado (interacción significativa) después del enterramiento de las parcelas. Así, una interacción significativa indicaría impactos de enterramiento significativos, mientras que una interacción no significativa indicaría impactos no detectables. Si se obtuvo un término de interacción significativa, se realizaron comparaciones múltiples con la prueba HSD de Tukey entre los tratamientos para investigar más a fondo la respuesta de la macrofauna.

Para todos los análisis, la significación se definió como $\alpha=0.05$. El índice de diversidad de Shannon-Wiener se calculó con Primer v6.0 y todas las pruebas estadísticas (incluyendo el análisis del poder estadístico para las pruebas realizadas) se realizaron con SigmaPlot 11.0, después de confirmar los supuestos de las pruebas paramétricas.

\section{RESULTADOS}

Antes del enterramiento, la densidad de C. nodosa

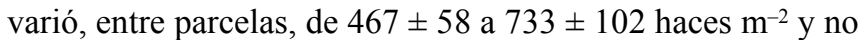
hubo diferencias significativas entre tratamientos $\left(F_{2,6}=3.09\right.$; $P=0.12$ ). Los tres tratamientos mostraron un aumento en la altura de la superficie foliar 5 días después del comienzo del experimento, pero el aumento fue mayor en las parcelas sometidas a enterramiento intenso (fig. 3$)\left(F_{2,6}=6.80 ; P=\right.$ 0.029; prueba HSD de Tukey, control vs intenso $P=0.0312$, control vs moderado $P=0.0671$, moderado vs intenso $P=$ 0.8115).

El experimento fue diseñado para estudiar la respuesta de la macrofauna a un enterramiento durante un periodo de casi 
However, we unexpectedly lost four of the nine plots (one control, two moderate, and one intense) by day 54 after burial. We could not find the rebar stakes for those plots and the sediment in the three lost plots that were initially buried had been washed away so that the plots were indistinguishable from the surrounding natural bottom. This in itself represents an interesting observation because it suggests that small-scale, pulse burial events may not be long lived in the location studied. Indeed, the location was an area with large fetch and typically exposed to intense winds and waves. This loss imbalanced the ANOVA design and, in fact, there was no replication for moderate burial on day 54. In addition, the two remaining control plots gained sediment $(\sim 3 \mathrm{~cm}$, see below) and could not be considered true controls anymore. Therefore, we restricted our two-way repeated-measures ANOVA to the first 5 days of the experiment. To gain further insight on the effects of burial over the duration of the experiment (54 days), we compared intense burial plots on days 5 and 54 with a paired $t$-test and put this comparison in the context of the ANOVA results for the first 5 days.

\section{Sediment dynamics and response to burial over 5 days}

When sediment depth was compared across all three treatments over 5 days since burial, there was a significant interaction between treatment and time $\left(F_{4,15}=3.63 ; \mathrm{P}=\right.$ 0.0292; fig. 2). For each time, pairwise tests were performed and all three burial treatments remained distinct for the first 5 days of the experiment (Tukey HSD, $P<0.05$; fig. 2). Although sediment depth at the intense burial plots decreased and tended to converge toward moderate burial plots, both moderate and intense burial plots had significantly greater sediment depth than controls (fig. 2).

A total of 12 higher macrobenthic taxa were identified in our samples (table 1). Bivalves, polychaetes, and gastropods were the dominant taxa, with rarer taxa including oligochaetes, decapods, and amphipods. Abundance results were very similar whether analyzed by surface area or volume (table 2). There was no significant interaction between treatment and time for live or total taxa expressed on an areal or volumetric basis (table 2, fig. 4), suggesting no significant burial effects on macrofaunal abundance.

We found a significant treatment-time interaction for live taxa richness, indicating a significant burial effect (table 2, fig. 5). Live taxa richness did not differ significantly among treatments before burial; however, on day 3 after burial, control plots had greater richness than intense and moderate burial plots. Interestingly, such significant differences among treatments had disappeared by day 5 after burial (fig. 5), suggesting quick recovery from the negative burial impacts found within the first three days of the experiment. Control plots consistently contained gastropods, bivalves, and polychaetes, but on day 3 we also found decapods, isopods, oligochaetes, and amphipods, resulting in the highest richness values recorded during the experiment. Moderate dos meses (54 días); sin embargo, inesperadamente se perdieron cuatro de las nueve parcelas (una parcela control, dos parcelas de enterramiento moderado y una de enterramiento intenso) antes del día 54 del experimento. No fue posible encontrar las piquetas para esas parcelas y el sedimento vertido en las tres parcelas perdidas había sido arrastrado por el mar por lo que estas parcelas eran indistinguibles del fondo natural circundante. Esto resulta ser interesante ya que sugiere que los eventos de enterramiento súbito y puntual a pequeña escala son de poca duración en el sitio de estudio, el cual se ubica en una zona abierta y típicamente expuesta a vientos intensos y fuerte oleaje. Esta pérdida generó un desbalance en el diseño del ANOVA y, de hecho, no hubo una replicación para enterramiento moderado al día 54. Además, las dos parcelas control restantes ganaron sedimento $(\sim 3 \mathrm{~cm}$, ver abajo) y ya no podían ser consideradas controles verdaderos. Por lo tanto, restringimos el ANOVA de dos vías con medidas repetidas a los primeros 5 días del experimento. Para un mayor entendimiento de los efectos del enterramiento a lo largo del experimento (54 días), se compararon las parcelas con enterramiento intenso a los días 5 y 54 mediante una prueba $t$ por pares y se puso esta comparación en contexto de los resultados del ANOVA para los primeros 5 días.

\section{Dinámica sedimentaria y respuesta a enterramiento durante 5 días}

Al comparar la profundidad del sedimento en los tres tratamientos durante 5 días de enterramiento se observó una interacción significativa entre el tratamiento y el tiempo $\left(F_{4,15}=3.63 ; P=0.0292\right.$; fig. 2$)$. Para cada tiempo se realizaron pruebas por pares y los tres tratamientos permanecieron distintos durante los primeros 5 días del experimento (prueba HSD de Tukey, $P<0.05$; fig. 2). A pesar de que la profundidad del sedimento en las parcelas sometidas a enterramiento intenso disminuyó y presentó una tendencia a igualarse a la de las parcelas sometidas a enterramiento moderado, la profundidad del sedimento en las parcelas de enterramiento tanto moderado como intenso fue mayor que en las parcelas control (fig. 2).

Se identificó un total de 12 taxones superiores de macrofauna bentónica (tabla 1). Los bivalvos, poliquetos y gasterópodos fueron los taxones dominantes, y entre los menos comunes se encontraron los oligoquetos, decápodos y anfípodos. Los resultados en cuanto a abundancia fueron similares analizados ya sea por área de superficie o volumen (tabla 2). No se observó una interacción significativa entre tratamiento y tiempo para la fauna viva o total expresada en base al área de superficie o volumen (tabla 2, fig. 4), lo que sugiere que el enterramiento no afectó significativamente la abundancia macrofaunal.

Se encontró una interacción significativa entre tratamiento y tiempo para la riqueza de taxones vivos, lo que 
Table 1. Mean total (live + dead) abundance $( \pm \mathrm{SD})$ per square decimeter of the higher order taxa encountered in the Cymodocea nodosa seagrass bed examined during a short-term burial experiment.

Tabla 1. Abundancia media ( \pm DE) por decímetro cuadrado de la fauna total (viva + muerta) de taxones superiores encontrada en el prado de la fanerógama marina Cymodocea nodosa examinado en un experimento de enterramiento a escala pequeña.

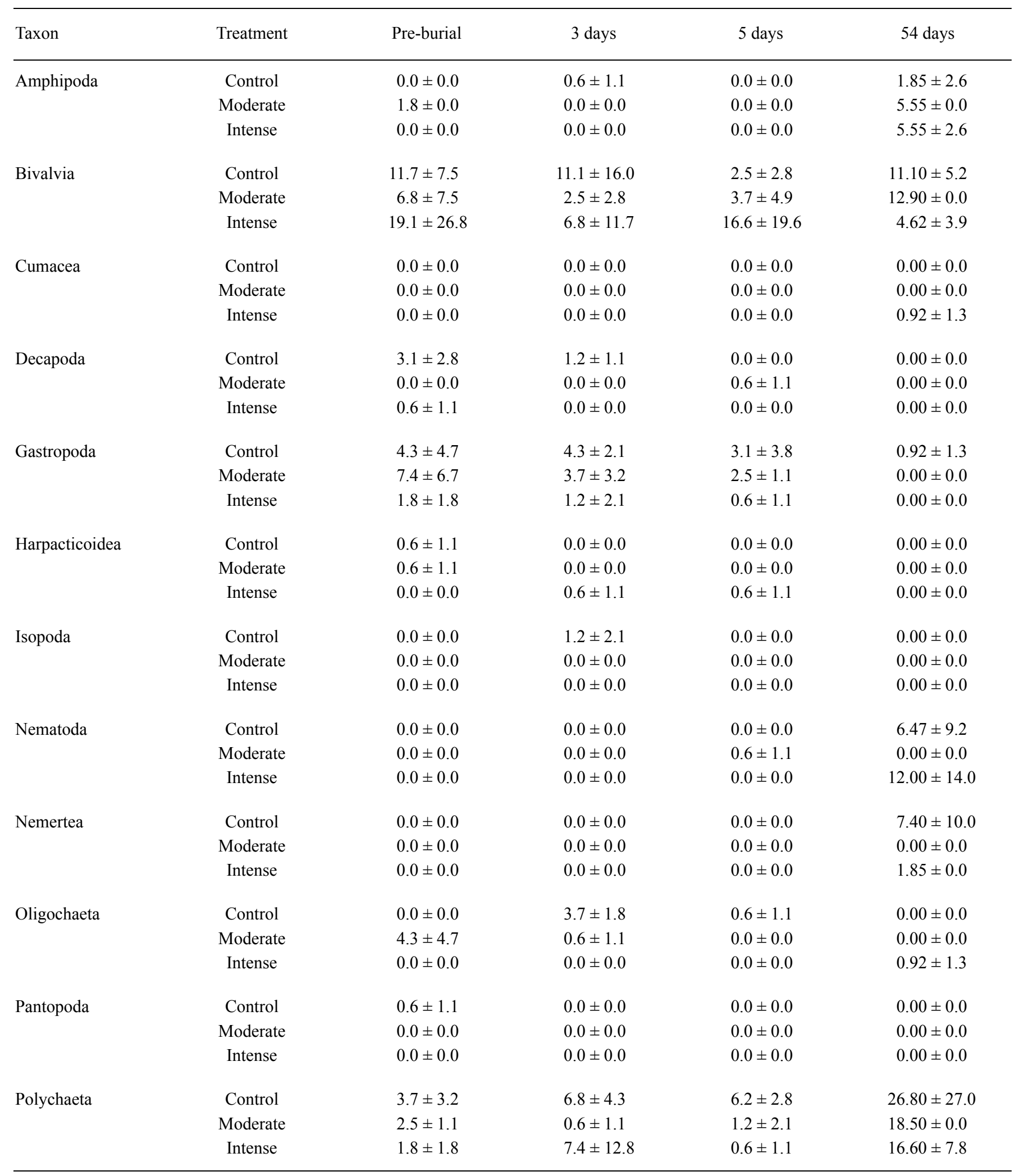


Table 2. Results of the two-way repeated-measures ANOVAs conducted on macrofaunal abundance (\# individuals), taxa richness (\# taxa), and the Shannon-Weiner diversity index $\left(\mathrm{H}^{\prime}\right)$. Data were analyzed per surface area and per volume for abundance, with treatment as a factor and time as the repetitive measure. Power $(1-\beta)$ is the power of the performed test.

Tabla 2. Resultados de los análisis de varianza de dos vías con medidas repetidas realizados para la abundancia macrofaunal (\# individuos), riqueza de taxones (\# taxones) y el índice de diversidad de Shannon-Weiner $\left(\mathrm{H}^{\prime}\right)$. Los datos se analizaron por área de superficie y por volumen para abundancia, con tratamiento como factor y tiempo como la medida repetida. La potencia $(1-\beta)$ es la potencia de la prueba realizada.

\begin{tabular}{|c|c|c|c|c|c|c|c|c|c|c|c|c|}
\hline & \multicolumn{4}{|c|}{ Abundance } & \multicolumn{4}{|c|}{ Taxa richness } & \multicolumn{4}{|c|}{ Diversity $\left(\mathrm{H}^{\prime}\right)$} \\
\hline & df & $F$ & $P>F$ & $1-\beta$ & df & $F$ & $P>F$ & $1-\beta$ & $\mathrm{df}$ & $F$ & $P>F$ & $1-\beta$ \\
\hline \multicolumn{13}{|l|}{ Live fauna } \\
\hline Treatment & 2 & 1.10 & 0.393 & 0.16 & 2 & 15.05 & 0.005 & 0.96 & 2 & 25.14 & 0.001 & 1.00 \\
\hline \multicolumn{13}{|l|}{ Total fauna } \\
\hline Treatment & 2 & 0.73 & 0.514 & 0.05 & 2 & 4.95 & 0.027 & 0.59 & 2 & 18.22 & 0.001 & 1.00 \\
\hline Time & 2 & 2.30 & 0.122 & 0.27 & 2 & 1.96 & 0.167 & 0.20 & 2 & 1.52 & 0.252 & 0.13 \\
\hline Treatment $\times$ time & 4 & 0.33 & 0.910 & 0.05 & 4 & 2.19 & 0.106 & 0.32 & 4 & 1.04 & 0.441 & 0.06 \\
\hline Time & 2 & 4.04 & 0.046 & 0.47 & & & & & & & & \\
\hline Treatment $\times$ time & 4 & 0.87 & 0.511 & 0.05 & & & & & & & & \\
\hline \multicolumn{13}{|l|}{ Total fauna } \\
\hline Treatment & 2 & 2.74 & 0.128 & 0.73 & & & & & & & & \\
\hline Time & 2 & 1.74 & 0.205 & 0.07 & & & & & & & & \\
\hline Treatment $\times$ time & 4 & 0.55 & 0.764 & 0.05 & & & & & & & & \\
\hline
\end{tabular}

and intense burial plots also consistently contained gastropods, bivalves, and polychaetes, with occasional appearance of nematodes or copepods. Total taxa richness (i.e., summing alive and dead individuals) was seemingly not affected by burial as indicated by the nonsignificant interaction term (table 2, fig. 5). Burial also did not seem to affect live and total diversity (table 2, fig. 5).

\section{Sediment dynamics over 54 days and comparison of intense burial plots between days 5 and 54}

By day 54 since burial some additional sedimentation had occurred on the remaining plots (ca $3 \mathrm{~cm}$ for control, ca $8 \mathrm{~cm}$ for moderate, and ca $5 \mathrm{~cm}$ for intense plots; fig. 2). This suggests that, once deposited, sediment in the study location moves around rather quickly, a suggestion that is also backed by the observation that three of the initially buried plots had been completely washed away by day 54 . The two remaining intense burial plots, however, had significantly higher sediment depth than the control plots $(t=105, P=0.006)$.

Admittedly, the remaining control plots on day 54 could no longer serve as true controls because of the unexpected sediment deposition. Nevertheless, we took advantage of the indica que el enterramiento tuvo un efecto significativo (tabla 2, fig. 5). La riqueza de taxones vivos no difirió significativamente entre los tratamientos antes del enterramiento; sin embargo, para el día 3 después del evento, las parcelas control presentaron una mayor riqueza que las parcelas sometidas a enterramiento moderado e intenso. Curiosamente, estas diferencias significativas entre los tratamientos habían desaparecido para el día 5 (fig. 5), lo que sugiere una recuperación rápida de los impactos negativos del enterramiento observados durante los primeros tres días del experimento. En las parcelas control, consistentemente se observaron gasterópodos, bivalvos y poliquetos, pero el día 3 también se encontraron decápodos, isópodos, oligoquetos y anfípodos, por lo que se registraron los valores más altos de riqueza durante el experimento. Las parcelas enterradas también consistentemente presentaron gasterópodos, bivalvos y poliquetos, y ocasionalmente nematodos o copépodos. La riqueza taxonómica total (i.e., individuos vivos + muertos) aparentemente no resultó afectada por el enterramiento según lo demuestra el término de interacción no significativa (tabla 2, fig. 5). El enterramiento aparentemente tampoco afectó la diversidad viva y total (tabla 2, fig. 5). 

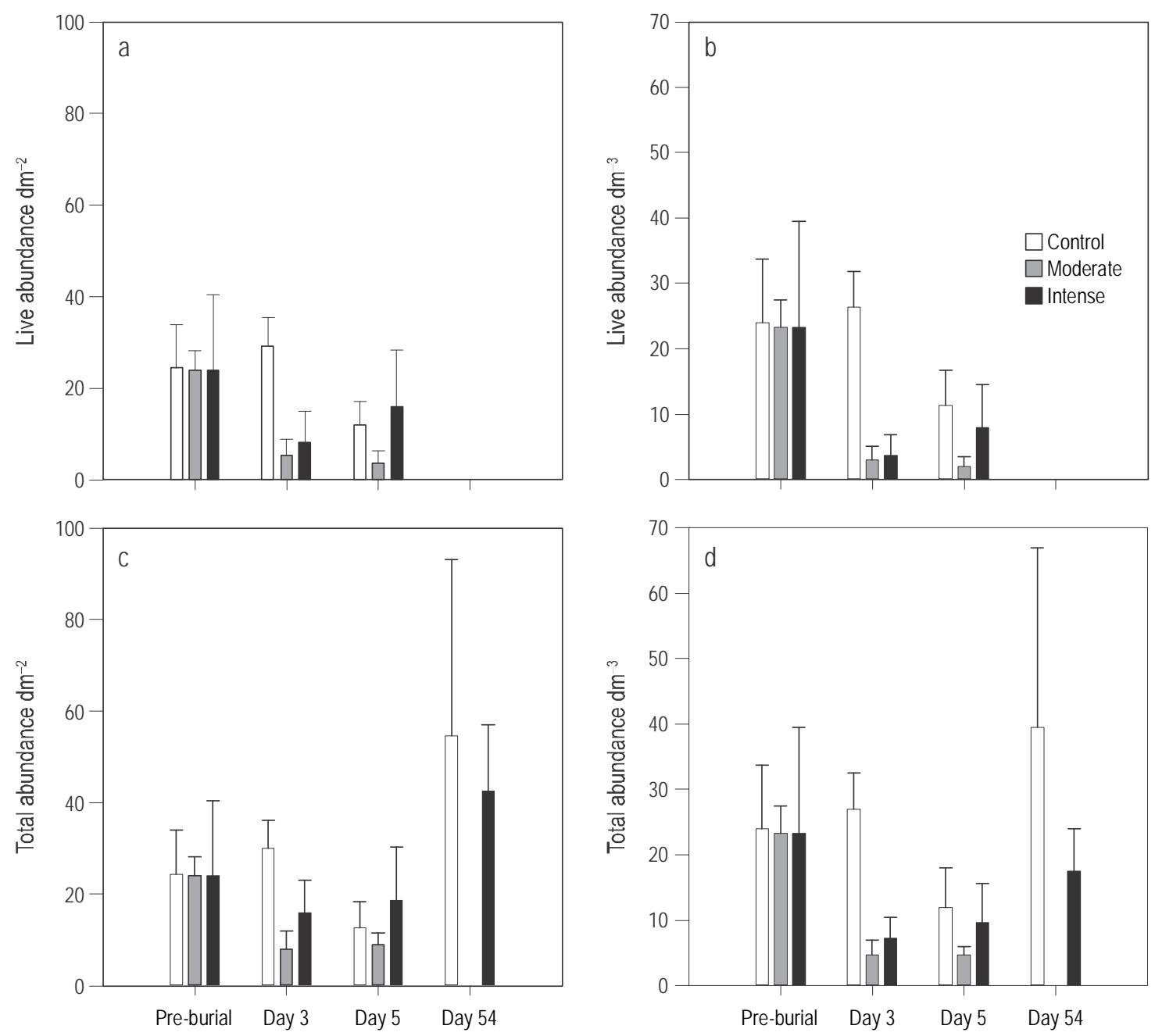

Figure 4. Mean abundance of Cymodocea nodosa-associated benthic macrofauna in response to sediment burial over 54 days. Panels (a) and (c) represent live and total abundance, respectively, by area. Panels (b) and (d) represent live and total abundance, respectively, by volume.

Figura 4. Abundancia media de la macrofauna bentónica asociada a Cymodocea nodosa en respuesta a 54 días de enterramiento por sedimento. Los paneles (a) y (c) representan la abundancia de fauna viva y total, respectivamente, por área de superficie. Los paneles (b) y (d) representan la fauna viva y total, respectivamente, por volumen.

fact that two of the intense burial plots still remained on day 54 and compared, using paired $t$-tests, the two intense burial plots between day 5 and 54 to gain further insight into burial effects. There were no significant differences for total abundance expressed on an areal $(t=0.618, P=0.648$, power $=$ $0.093)$ or volumetric $(t=0.394, P=0.761$, power $=0.093)$ basis, nor for total richness $(t=9.0, P=0.07$, power $=0.51)$; however, total diversity was greater on day 54 than on day 5 $(t=158.31, P=0.004$, power $=1.00)$.

\section{DISCUSSION}

Our experiment was designed to examine the effects of a single pulse, small-scale burial event on the C. nodosaassociated macrofaunal community. Due to unexpected events (i.e., loss of four of nine experimental plots due to sediment dispersion), we have primarily focused on the

\section{Dinámica sedimentaria durante 54 días y comparación de las parcelas sometidas a enterramiento intenso entre los días 5 y 54}

Después de 54 días del experimento se observó sedimentación adicional en las parcelas aún existentes (ca 3,8 y $5 \mathrm{~cm}$ en las parcelas control, de enterramiento moderado y de enterramiento intenso, respectivamente; fig. 2). Esto sugiere que, una vez depositado, el sedimento en el sitio de estudio se mueve de un lugar a otro con bastante rapidez, una sugerencia que también es respaldada por el hecho de que tres de las parcelas originalmente enterradas habían desaparecido para el día 54. Las dos parcelas de enterramiento intenso restantes, sin embargo, presentaron una profundidad de sedimento significativamente mayor que las parcelas control $(t=105$, $P=0.006)$. 

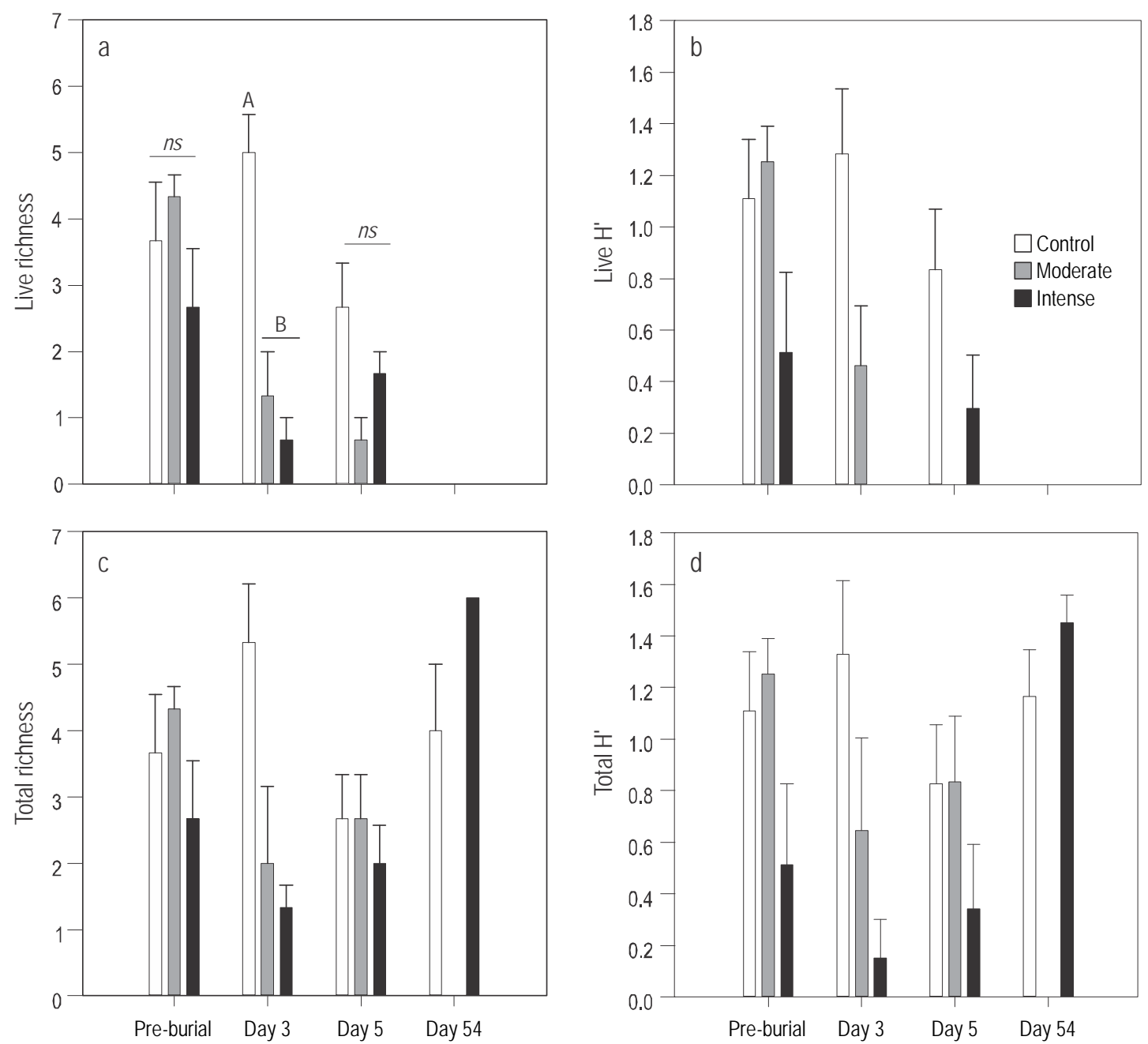

Figure 5. Mean live (a) and total (c) macrofaunal richness in response to 54 days of burial. Panels (b) and (d) represent mean live and total Shannon-Wiener diversity $\left(\mathrm{H}^{\prime}\right)$, respectively. Letters in (a) denote the results of the Tukey HSD test comparing burial treatments at each sampling time, after a significant interaction term from the two-way repeated-measures analysis of variance; ns denotes not significant.

Figura 5. Riqueza media de la macrofauna viva (a) y total (c) en respuesta a 54 días de enterramiento. Los paneles (b) y (d) representan la diversidad media de la macrofauna viva y total (índice de Shannon-Wiener, H'), respectivamente. Las letras en (a) señalan los resultados de la comparación de los tratamientos de enterramiento en cada tiempo de muestreo mediante la prueba HSD de Tukey, depués de un término de interacción significativa del análisis de varianza de dos vías con medidas repetidas; $n s$ indica no significativo.

results up to 5 days after burial. We found a significant decrease in live taxa richness in buried plots in relation to control plots 3 days after burial. The decrease was similar for moderate $(7 \mathrm{~cm})$ and intense $(13 \mathrm{~cm})$ burial in relation to control conditions. Past studies have also found reduced taxonomic diversity following burial in Florida (Rakocinski et al. 1996) and in North Carolina (Peterson et al. 2000). Burial seems to have adverse impacts for some of the taxa reported in our study. However, gastropods, bivalves, and polychaetes were consistently identified in cores, regardless of burial treatment or length of time, suggesting that these taxa in particular possess mechanisms to deal with sedimentation events. These mechanisms are likely species-specific (as shown in, e.g., Defeo et al. 1997, Leewis et al. 2012, Van
Hay que reconocer que las parcelas control que aún permanecían para el día 54 ya no servían como verdaderos controles por el depósito inesperado de sedimento. No obstante, aprovechamos el hecho que dos de las parcelas sometidas a enterramiento intensivo aún permanecían para el día 54 y se compararon, mediante pruebas $t$ por pares, entre los días 5 y 54 para entender mejor los efectos del enterramiento. No se observaron diferencias significativas para la abundancia total analizada en base al área de superficie $(t=0.618, P=0.648$, potencia $=0.093)$ o volumen $(t=0.394$, $P=0.761$, potencia $=0.093)$, ni para la riqueza total $(t=9.0$, $P=0.07$, potencia $=0.51)$; sin embargo, la diversidad total fue mayor el día 54 que el día $5(t=158.31, P=0.004$, potencia $=1.00)$. 
Tomme et al. 2013) and dependent on the depth, duration, and frequency of burial (e.g., Nichols et al. 1978, Lynch 1994, Schratzberger et al. 2000). Various species are able to migrate considerable distances through the sediment and some individuals can be found at depths up to $30 \mathrm{~cm}$ (e.g., polychaetes in a C. nodosa bed off the Canary Islands, Brito et al. 2005). We did not find a significant impact of burial on total taxa richness (i.e., combining alive and dead individuals), possibly because dead taxa in buried plots elevated taxa richness in those plots to levels similar to controls. The statistical power for the analysis of total taxa richness was low, though, and that could be an additional reason why we did not find a statistically significant effect of burial on this metric.

We also did not find significant effects of burial on live abundance (either expressed on an areal or volumetric basis) or diversity. Previous reports have found significant impacts of burial on these macrofaunal metrics (e.g., Peterson et al. 2000, Menn et al. 2003), but others have not. For example, Gorzelany and Nelson (1987) did not find a significant impact on abundance or richness of benthic fauna in response to burial from beach nourishment on the east coast of Florida, and Leewis et al. (2012) found no long-term negative effects of beach nourishment on the abundance of four dominant species of beach macrofauna in the Netherlands. In our study the statistical power for the analyses of abundance and diversity is low, and it is likely that we have not detected significant burial impacts on these metrics due to limited sample size. Indeed, visually, the plots of live abundance in figure $4(a, b)$ and diversity in figure 5(b) suggest a negative effect of burial on these metrics, particularly on day 3 , but the differences are not statistically significant.

In addition to low replication, the inherent variability in distribution that macrofaunal communities typically exhibit (e.g., Minshall and Minshall 1977, Underwood and Chapman 1996) represents another potential reason as to why we have not found a significant effect of burial on live abundance and diversity in our study. Finally, it may also have been that the abundance of some taxa was depressed due to the season when our experiment was done and/or the time of day of sampling. For instance, the first days of the experiment were in early September, and Gambi et al. (1998) found that polychaetes showed the lowest diversity and abundance in other shallow Mediterranean areas during the summer. In addition, our sampling took place during daytime, and Raso et al. (2006) noted that decapods were more abundant at night and several species of hermit crabs were rare or absent during the day in C. nodosa beds. Therefore, low abundances due to seasonal or diel forcing may have contributed to further mask burial impacts in our study. We did not find statistically significant effects on total abundance and diversity, most likely because, along with the potential reasons mentioned above, dead animals raised these metrics in buried plots to values similar to those in control plots.

\section{DISCUSIÓN}

Este experimento fue diseñado para examinar los efectos de un enterramiento súbito y puntual a pequeña escala en la comunidad de fauna macrobentónica asociada a C. nodosa. Debido a eventos inesperados (i.e., pérdida de cuatro de las nueve parcelas experimentales por dispersión de sedimento), se enfocó principalmente en los resultados obtenidos para los primeros 5 días del experimento. Tres días después del enterramiento se observó una disminución significativa de la riqueza de taxones vivos en las parcelas enterradas en relación con las parcelas control. La disminución fue similar para las parcelas sometidas a enterramiento moderado $(7 \mathrm{~cm}) \mathrm{e}$ intenso $(13 \mathrm{~cm})$ en relación con las parcelas control. Estudios previos también han documentado una reducida diversidad taxonómica después de eventos de enterramiento en Florida (Rakocinski et al. 1996) y Carolina del Norte (Peterson et al. 2000). El enterramiento parece tener efectos adversos para algunos de los taxones encontrados en este estudio; sin embargo, los gasterópodos, bivalvos y poliquetos consistentemente aparecieron en los núcleos, independientemente del tratamiento o tiempo, lo que sugiere que estos taxones en particular poseen mecanismos para hacer frente a los eventos de sedimentación. Estos mecanismos probablemente sean específicos de las especies (como lo demuestran, e.g., Defeo et al. 1997, Leewis et al. 2012, Van Tomme et al. 2013) y dependientes de la profundidad, duración y frecuencia de los enterramientos (e.g., Nichols et al. 1978, Lynch 1994, Schratzberger et al. 2000). Varias especies son capaces de migrar distancias considerables a través del sedimento y algunos inidividuos pueden llegar hasta profundidades de $30 \mathrm{~cm}$ (i.e., poliquetos en una pradera de $C$. nodosa en las islas Canarias, Brito et al. 2005). En el presente estudio no observamos un impacto significativo en la riqueza taxonómica total (e.g., individuos vivos + muertos), posiblemente porque la fauna muerta en las parcelas enterradas elevó la riqueza taxonómica en esos parceles a niveles similares a los de las parcelas control. No obstante, el poder estadístico para el análisis de la riqueza taxonómica total fue baja y esto también podría explicar por qué el enterramiento no afectó significativamente esta métrica.

Tampoco se observaron efectos significativos del enterramiento sobre la abundancia (analizada ya sea por área de superficie o volumen) o diversidad de individuos vivos. Reportes previos han documentado impactos significativos en estas métricas macrofaunales (e.g., Peterson et al. 2000, Menn et al. 2003), pero otros no. Por ejemplo, Gorzelany y Nelson (1987) no observaron un impacto significativo en la abundancia o riqueza de fauna bentónica en respuesta a un enterramiento debido al relleno de una playa en la costa este de Florida, y Leewis et al. (2012) no encontraron efectos negativos a largo plazo de la regeneración de playas sobre la abundancia de cuatro especies dominantes de la macrofauna playera en los Países Bajos. En el presente estudio, el poder estadístico para los análisis de abundancia y diversidad fue 
Our results suggest that, despite evidence for deleterious impacts on the macroinvertebrate community 3 days after burial, signs of recovery may occur as early as 5 days after burial. Buried plots had significantly lower live taxa richness than control plots on day 3 , but the decreased richness did not persist after 5 days. This may have been caused by a reduction in richness for control plots from day 3 to day 5 rather than by an increase for buried plots from day 3 to day 5 . The visual examination of the results for live abundance and diversity also suggest that the differences between control and buried plots found on day 3 are somewhat dampened by day 5 , but this is only speculative since we did not find any statistically significant differences between plots for these metrics.

The comparison of intense burial plots at 5 and 54 days after burial appears to provide further evidence that macrofaunal communities may recover from single small burial pulses. Although not statistically significant, the values of total abundance (both on an areal and volumetric basis) and richness in intense burial plots found on day 54 are elevated in comparison with the values found on day 5. Total diversity in intense burial plots was significantly higher on day 54 than on day 5. In concert, these comparisons indicate elevated abundance, richness, and diversity in the two remaining intense burial plots 54 days after burial in relation to the values found in those plots 5 days after burial. The evidence for recovery provided by the comparison of intense buried plots at days 5 and 54 can only be conjectural, however, because (1) most of those differences were not statistically significant, (2) we did not have true controls anymore at day 54 , and (3) we did not know the relative abundance of alive and dead fauna for total counts at day 54. Nevertheless, these results do at least suggest that macrofaunal recovery from a single pulse, small-scale burial event is possible within weeks. In fact, prior work has reported partial or full recovery of macrofauna to burial events over periods lasting from months to years (e.g., Hackney et al. 1996, Rakocinski et al. 1996).

We admit that the findings of this study are somewhat limited; however, they do offer suggestive evidence that single, small scale burial pulses can have detrimental impacts on higher-taxa macrofaunal communities of C. nodosa beds, and that the communities can recover within weeks. Herein, we restricted our discussion to higher taxa and acknowledge that examining lower level taxa would provide specific responses of taxa and a more thorough understanding of burial effects on these seagrass beds. To our knowledge this is the first study to directly examine the effects of burial on benthic macrofauna associated with $C$. nodosa and thus we believe our findings have value since this topic has been little studied. Fast recovery by higher-taxa macrofaunal communities in C. nodosa beds could be an adaptation to frequent sediment deposition and movement in the shallow coastal areas where these beds typically exist. More research is needed to fully characterize the impacts of burial regimes varying in bajo y es probable que no se hayan detectados efectos significativos del enterramiento en estas métricas debido al tamaño de muestra limitado. De hecho, las gráficas de la abundancia (fig. 4a, b) y diversidad (fig. 5b) de individuos vivos visualmente sugieren un efecto negativo del enterramiento sobre estas métricas, especialmente el día 3, pero las diferencias no son estadísticamente significativas.

Además de la baja replicación, la variabilidad inherente de la distribución típicamente exhibida por las comunidades macrofaunales (e.g., Minshall y Minshall 1977, Underwood y Chapman 1996) representa otra razón potencial de por qué el enterramiento no tuvo un efecto significativo en la abundancia y diversidad de individuos vivos. Es posible que la abundancia de algunos taxones haya sido menor debido a la temporada del año y/o la hora del día en que se realizaron los muestreos. Nuestro experimento comenzó a principios de septiembre y, según Gambi et al. (1998), la diversidad y abundancia de poliquetos en otras zonas someras del Mediterráneo es menor en verano. Así mismo, nuestros muestreos se realizaron durante el día y Raso et al. (2006) registraron una mayor abundancia de decápodos durante la noche y una ausencia o baja presencia de varias especies de cangrejos ermitaños durante el día en praderas de $C$. nodosa. Por lo tanto, las bajas abundancias relacionadas con forzamientos estacionales o diurnos podrían haber contribuido a enmascarar aún más los impactos del enterramiento. No se observaron efectos estadísticamente significativos en la abundancia y diversidad total, probablemente porque, además de las razones mencionadas arriba, los animales muertos elevaron estas métricas en las parcelas enterradas a valores similares a los de las parcelas control.

Nuestros resultados sugieren que, a pesar de la evidencia de efectos deleitérios sobre la comunidad de macroinvertebrados 3 días después del enterramiento, se pueden observar signos de recuperación tan pronto como 5 días depués del evento. La riqueza de taxones vivos en las parcelas enterradas fue significativamente menor que en las parcelas control 3 días después del enterramiento, pero esta menor riqueza no persistió después de 5 días. Esto podría deberse más bien a una disminución de la riqueza en las parcelas control del día 3 al día 5 que a un aumento en las parcelas enterradas durante estos días. Las gráficas de la abundancia y diversidad de individuos vivos sugieren que las diferencias entre las parcelas control y las enterradas el día 3 son menos aparentes el día 5, pero esto es sólo una especulación ya que no se encontraron diferencias estadísticamente significativas entre las gráficas para estas métricas.

La comparación de las parcelas después de 5 y 54 días de enterramiento intensivo proporciona mayor evidencia de que las comunidades macrofaunales pueden recuperarse de un enterramiento súbito y puntual. Los valores de abundancia total (tanto por área de superficie como volumen) y de riqueza total registrados el día 54 son altos en comparación con los registrados el día 5, aunque no se detectaron diferencias significativas. La diversidad total de las parcelas 
intensity, duration, and frequency on macrofaunal communities in seagrass beds. Particular attention should be given to shallow beds exposed to high sediment dynamics as well as factors that may regulate the macrofaunal response to burial, such as intra- and inter-specific competition, migration potential, facilitation processes, and substrate preference.

\section{ACKNOWLEDGMENTS}

The authors acknowledge the University of South Alabama, the Dauphin Island Sea Lab, the University of Alicante, and CIMAR for their collaboration and funding to make this study-abroad-class experiment possible. Support for DJ Dalrymple, ES Darrow, and MN Schrandt was provided by the Department of Marine Sciences, University of South Alabama. The authors also thank the anonymous reviewers whose comments improved the manuscript.

\section{REFERENCES}

Brito MC, Martin D, Nunez J. 2005. Polychaetes associated to a Cymodocea nodosa meadow in the Canary Islands: Assemblage structure, temporal variability, and vertical distribution compared to other Mediterranean seagrass meadows. Mar. Biol. 146: 467-481.

Cabaço S, Santos R. 2007. Effects of burial and erosion on the seagrass Zostera noltii. J. Exp. Mar. Biol. Ecol. 340: 204-212.

Cabaço S, Santos R, Duarte CM. 2008. The impact of sediment burial and erosion on seagrasses: A review. Estuar. Coast. Shelf Sci. 79: 354-366.

Colosio F, Abbiati M. Airoldi L. 2007. Effects of beach nourishment on sediments and benthic assemblages. Mar. Pollut. Bull. 54: 1197-1206.

Defeo O, Brazeiro A, de Alava A, Riestra G. 1997. Is sandy beach macrofauna only physically controlled? Role of substrate and competition in isopods. Estuar. Coast. Shelf. Sci. 45: 453-462.

Dethier MN, Schoch GC. 2006. Taxonomic sufficiency in distinguishing natural spatial patterns on an estuarine shoreline. Mar. Ecol. Prog. Ser. 306: 41-49.

Duarte CM. 2002. The future of seagrass meadows. Environ. Conserv. 29: 192-206.

Duarte CM, Sand-Jensen K. 1990. Seagrass colonization: Biomass development and shoot demography in Cymodocea nodosa patches. Mar. Ecol. Prog. Ser. 67: 97-103.

Duarte CM, Terrados J, Agawin NSR, Fortes MD, Bach S, Kenworthy WJ. 1997. Response of a mixed Philippine seagrass meadow to experimental burial. Mar. Ecol. Prog. Ser. 147: 285-294.

Erftemeijer PLA, Robin Lewis III RR. 2006. Environmental impacts of dredging on seagrasses: A review. Mar. Pollut. Bull. 52: $1553-1572$.

Espino F, Tuya F, Brito A, Haroun RJ. 2011. Ichthyofauna associated with Cymodocea nodosa meadows in the Canarian Archipelago (central eastern Atlantic): Community structure and nursery role. Cienc. Mar. 37: 157-174.

Gambi MC, Conti G, Bremec CS. 1998. Polychaete distribution, diversity and seasonality related to seagrass cover in shallow soft bottoms of the Tyrrhenian Sea (Italy). Sci. Mar. 62: 1-17.

González-Correa JM, Fernández-Torquemada Y, Sánchez-Lizaso JL. 2009. Short-term effect of beach replenishment on a shallow Posidonia oceanica meadow. Mar. Environ. Res. 68: 143-150. sometidas a enterramiento intensivo fue significativamente mayor el día 54 que el día 5 . Así mismo, estas comparaciones indican una elevada abundancia, riqueza y diversidad en las dos parcelas del tratamiento intensivo que aún existían para el día 54 en comparación con los valores registrados después de 5 días. La evidencia de recuperación proporcionada por la comparación de las parcelas sometidas a enterramiento intensivo durante 5 y 54 días sólo puede ser conjetural, ya que (1) la mayoría de las diferencias no fueron estadísticamente significativas, (2) para el día 54 ya no existían controles verdaderos y (3) no se determinó la abundancia relativa de la fauna viva y muerta para los conteos totales. No obstante, estos resultados sugieren que la macrofauna se puede recuperar de un enterramiento repentino y puntual a pequeña escala en el plazo de unas semanas. De hecho, estudios previos han documentado una recuperación total o parcial de la macrofauna después de enterramientos de meses a años de duración (e.g., Hackney et al. 1996, Rakocinski et al. 1996).

A pesar de que los resultados del presente trabajo son algo limitados, ofrecen evidencia sugerente de que los eventos repentinos y puntuales de enterramiento a pequeña escala pueden tener efectos negativos sobre las comunidades macrobentónicas de taxones superiores asociadas a C. nodosa, y que las comunidades se pueden recuperar dentro de unas semanas. Aquí limitamos nuestra discusión a taxones superiores y reconocemos que una evaluación de los taxones de nivel inferior proporcionaría respuestas específicas de los taxones y un mejor entendimiento de los efectos de enterramiento en estas praderas de fanerógamas marinas. Según nuestro conocimiento, éste es el primer estudio que examina directamente los efectos de enterramiento en la macrofauna bentónica asociada a C. nodosa y, por lo tanto, consideramos que los resultados tienen valor ya que este tema ha sido poco estudiado. Una recuperación rápida por las comunidades macrofaunales de taxones superiores en las praderas de C. nodosa podría ser una adaptación al frecuente depósito y movimiento de sedimentos en zonas costeras someras donde típicamente se encuentran estas praderas. Se necesitan más estudios para caracterizar completamente los efectos de los eventos de enterramiento de diferente intensidad, duración y frecuencia sobre las comunidades macrofaunales en las praderas marinas. Se debe prestar especial atención a las praderas en zonas someras con alta sedimentación, así como a factores que pueden regular la respuesta de la macrofauna al enterramiento, tal como la competencia intraespecífica e interespecífica, el potencial migratorio, los procesos de facilitación y la preferencia de sustrato.

\section{Agradecimientos}

Los autores agradecen a la Universidad del Sur de Alabama, Dauphin Island Sea Lab, la Universidad de Alicante y CIMAR su colaboración y apoyo para poder realizar este experimento como parte de un programa para estudiar en el extranjero. DJ Dalrymple, ES Darrow y MN 
Gorzelany JF, Nelson WG. 1987. The effects of beach replenishment on the benthos of a sub-tropical Florida beach. Mar. Environ. Res. 21: 75-94.

Hackney CT, Posey MH, Ross SW, Norris AR. 1996. Review and synthesis of data on surf zone fishes and invertebrates in the South Atlantic Bight and the potential impacts from beach renourishment. US Army Corps of Engineers, Wilmington, NC, Technical Report, 20 pp.

Hinchey E, Schaffner L, Hoar C, Vogt B, Batte L. 2006. Responses of estuarine benthic invertebrates to sediment burial: The importance of mobility and adaptation. Hydrobiologia 556: 85-98.

Leewis L, van Bodegom PM, Rozema J, Janssen GM. 2012. Does beach nourishment have long-term effects on intertidal macroinvertebrate species abundance? Estuar. Coast. Shelf. Sci. 113: 172-181.

Lynch AE. 1994. Macrofaunal recolonization of Folly Beach, South Carolina, after beach nourishment. MSc thesis, University of Charleston, South Carolina, USA, 45 pp.

Manzanera M, Pérez M, Romero J. 1998. Seagrass mortality due to oversedimentation: An experimental approach. J. Coast. Conserv. 4: 67-70.

Manzanera M, Alcoverro T, Tomas F, Romero J. 2011. Response of Posidonia oceanica to burial dynamics. Mar. Ecol. Prog. Ser. 423: 47-56.

Marbà N, Duarte CM. 1994. Growth response of the seagrass Cymodocea nodosa to experimental burial and erosion. Mar. Ecol. Prog. Ser. 107: 307-311.

Marbà N, Cebrián J, Enriquez S, Duarte CM. 1994. Migration of large-scale subaqueous bedforms measured with seagrasses (Cymodocea nodosa) as tracers. Limnol. Oceanogr. 39: 126-133.

Marbà N, Cebrián J, Enriquez S, Duarte CM. 1996. Growth patterns of Western Mediterranean seagrasses: Species-specific responses to seasonal forcing. Mar. Ecol. Prog. Ser. 133: 203-215.

Martin D, Bertasi F, Colangelo MA, de Vries M, Frost M, Hawkins SJ, Macpherson E, Moschella PS, Satta MP, Thompson RC, Ceccherelli VU. 2005. Ecological impact of coastal defense structures on sediment and mobile fauna: Evaluating and forecasting consequences of unavoidable modifications of native habitats. Coast. Eng. 52: 1027-1051.

Menn I, Junghans C, Reise K. 2003. Buried alive: Effects of beach nourishment on the infauna of an erosive shore in the North Sea. Senckenb. Marit. 32: 125-145.

Minshall GW, Minshall JN. 1977. Microdistribution of benthic invertebrates in a Rocky Mountain (USA) stream. Hydrobiologia 55: 231-249.

Nichols JA, Rowe GT, Clifford CH, Young RA. 1978. In situ experiments on the burial of marine invertebrates. J. Sediment. Petrol. 48: 419-425.

Olsgard F, Somerfield PJ. 2000. Surrogates in marine benthic investigations - which taxonomic unit to target? J. Aquat. Ecosys. Stress Recovery 7: 25-42.
Schrandt recibieron apoyo del Departamento de Ciencias Marinas de la Universdidad del Sur de Alabama. Se agradece a los revisores anónimos cuyos comentarios ayudaron a mejorar el manuscrito.

Traducido al español por Christine Harris.

Orth RJ, Carruthers TJB, Dennison WC, Duarte CM, Fourqurean JW, Heck Jr KL, Hughes AR, Kendrick GA, Kenworthy WJ, Olyarnik S, Short FT, Waycott M, Williams SL. 2006. A global crisis for seagrass ecosystems. BioScience 56: 987-996.

Peterson CH, Hickerson DHM, Johnson GG. 2000. Short-term consequences of nourishment and bulldozing on the dominant large invertebrates of a sandy beach. J. Coast. Res. 16: 368-378.

Rakocinski CF, Heard RW, LeCroy SE, McLelland JA, Simons T. 1996. Responses by macrobenthic assemblages to extensive beach restoration at Perdido Key, Florida, USA. J. Coast. Res. 12: 326-353.

Raso JE, Martín MJ, Díaz V, Cobos V, Manjón-Cabeza ME. 2006. Diel and seasonal changes in the structure of a decapod (Crustacea: Decapoda) community of Cymodocea nodosa from southeastern Spain (West Mediterranean Sea). Hydrobiología 557: 59-68.

Schratzberger M, Rees HL, Boyd SE. 2000. Effects of simulated deposition of dredged material on structure of nematode assemblages - the role of burial. Mar. Biol. 136: 519-530.

Short FT, Wyllie-Echeverria S. 1996. Natural and human-induced disturbance of seagrasses. Environ. Conserv. 23: 17-27.

Terrados J. 1997. Is light involved in the vertical growth response of seagrasses when buried by sand? Mar. Ecol. Prog. Ser. 152: 295-299.

Thrush SF, Hewitt JE, Cummings VJ, Ellis JI, Hatton C, Lohrer A, Norkko A. 2004. Muddy waters: Elevating sediment input to coastal and estuarine habitats. Front. Ecol. Environ. 2: 299-306.

Tuya F, Pérez J, Medina L, Luque A. 2001. Seasonal variation of the macrofauna from three seagrass meadows of Cymodocea nodosa off Gran Canaria (central-eastern Atlantic Ocean). Cienc. Mar. 27: 223-234.

Underwood AJ, Chapman MG. 1996. Scales of spatial patterns of distribution of intertidal invertebrates. Oecologia 107: 212-224.

Van Tomme J, Eede SV, Speybroeck J, Degraer S, Vincx M. 2013. Macrofaunal sediment selectivity considerations for beach nourishment programmes. Mar. Environ. Res. 84: 10-16.

Warwick RM. 1988. The level of taxonomic discrimination required to detect pollution effects on marine benthic communities. Mar. Pollut. Bull. 19: 259-268.

Waycott M, Duarte CM, Carruthers TJB, Orth RJ, Dennison WC, Olyarnik S, Calladine A, Fourqurean JW, Heck Jr KL, Hughes AR, Kendrick GA, Kenworthy WJ, Short FT, Williams SL. 2009. Accelerating loss of seagrasses across the globe threatens coastal ecosystems. Proc. Natl. Acad. Sci. USA 106: 12377-12381.

Received October 2014, accepted February 2015. 